\title{
COLLABORATION AND CONTESTATION IN A DISPUTE ABOUT SPACE IN AN INDO-GUYANESE VILLAGE
}

\author{
Jack Sidnell
}

\section{Formulating place in interaction}

Researchers in linguistics and anthropology have often stressed the ways in which talk is anchored to locally established spatial frames through deictic usage (Hanks 1990, 1996a, 1996b, Schegloff 1972). Rather than "calques of objective spatial placement (Hanks 1996b:241)," deictics situate participants in relation to locally meaningful boundaries such as those established by property relations. Just as talk relies on locally meaningful spaces in order to anchor itself deictically, it also plays a role in the social construction of these spaces. Boundaries, borders, and the spaces they delimit become meaningful in part through talk situated within and anchored to them as well as through talk about them. This paper explores the way in which spatial organization is socially constructed through language and the way the meanings associated with particular places are negotiated in talk.

Because the regulation of bodies in space is so intimately tied to the exercise of social power (see Duranti 1994, Foucault 1979, Goodwin 1990: 81-84, Keating 1994), place-formulation in conversation often becomes the object of heated dispute. Thus the fact that participants work with an at least partially shared commonsense geography does not entail perfect agreement about the "rightness" of particular place-formulating moves in conversation. As such, in the following, I am concerned to show the way in which, while participants sometimes ratify one another's place-formulating moves, they do not always agree on particular characterizations of locatable spaces. Instead, participants tend construe space strategically to suit their own ends and achieve their own interactional goals. Spatial descriptions and place-formulations are resources which members draw on to invoke social relationships and interactionally relevant dimensions of social identity. Spaces also frequently become indexically linked to particular activities understood as habitually taking place within them (Moore 1986, Sidnell 1998a). Further, spatially motivated oppositions such as those between stability and movement may take on moral significance (Ochs 1988). At the same time, because space is almost always organized in relation to locally recognized 
forms of relationality (most notably kinship, but also gender and age), particular invocations of spatial arrangements can serve to foreground and make relevant certain relationships or even certain aspects of those relationships (such as obligations existing between kin). In addition to these social relationships made interactively relevant, spatial organization is also implicated in the semiotic negotiation of relationships more intricately tied to the particulars of an interactive engagement including participant alignment, opposition and authority.

I will explore these themes in an analysis of a dispute which took place in a small, rural Indo-Guyanese village. ${ }^{1}$ The language spoken is basilectal Guyanese Creole (GC) a variety which exhibits all the distinctive grammatical, lexical and phonological characteristics of Caribbean Creole English (cf. Rickford 1987, Winford 1990). Disputes of the kind I discuss in this paper are referred to locally as "war" /waar/, "fight" /fait/ or "busin" /buuzin/. ${ }^{2}$ They have a routinized and recognizable structure characterized by the alternating modes of dyadic exchange and extended monologue as well as by the issuance of complaints, insults and challenges. Although disputes like the one I discuss here sometimes involve men, they are an important means by which women make public appeals and criticize the existing local social order. ${ }^{3}$ Thus, each participant delivers their contribution to the dispute with increased amplitude so as to make the words hearable by passers-by on the road and others who for one reason or another are in the vicinity at the time. The overall effect is to create a kind of public forum for the discourse.

In the particular interaction I discuss here, the participants contest the way in which persons are related to socially recognized spaces in the village. More specifically, what they challenge in this interaction can be referred to as the local gendering of space. This has two aspects relevant to the current discussion. The first aspect manifests itself at the intersection of kinship, inheritance and spatial organization. Thus, in the village people are generally organized into patrilocal groups (Sidnell 1998a). These are corporate entities which hold land in common. Each group has one or several publicly recognized household heads; usually a father or two or more brothers. These men take it as their responsibility to maintain patrilocal group property and monitor the behavior of those inhabiting it. Inheritance is also generally patrilineal flowing from a male household head to his sons. If a male household head dies leaving a widow, the sons will often, at that time, make claims to patrilocal landholdings. The widow of the patriarch thus has limited rights to the property she has occupied during her married life. As authority in a great range of matters depends at least partially on rights to property, widowed women often find themselves at odds with their own sons who attempt to make claims to patrilineal inheritance and thereby also authority within the patrilocal group. The other important aspect of this local gendering of space is manifest at the intersection of local notions of morality, movement and spatial organization. In the village women are generally expected to stay close to the nuclear family's house. Here they are charged with the vast majority of the domestic labor. Fathers and husbands vigilantly police and regulate their movement. Members of the patrilocal group know that a woman who spends time outside the home may by suspected of carrying on illicit affairs. When suspicions of this kind lead to rumor, the patrilocal group into which the woman has married is shamed. Therefore, the men in that group including the inmarrying wife's husband as well as his father and brothers police her movement. Women 
who belong to the patrilocal group may also be involved in the policing of the in-marrying wives.

Women are far from resigned to this gendering of space and in fact they make special efforts to alleviate the way in which it restricts them (see Sidnell 1998b). For women, movement is essential to the maintenance of social relationships. As residence is primarily patrilocal, women must leave their houses to visit their own patrilocal group and maintain relationships with cognatic kin. These relationships are of central importance to a woman's livelihood in the village. Often estranged from their affines, married women must rely on their own patrilocal group for help in matters in which they do not want to involve their husband. Also if a woman quarrels with her husband she is unlikely to get support from her affines (their primary loyalty almost always going to members of their own patrilocal group). At times like these women can also call on the help of friends and time away from the house is important in maintaining these important ties. Movement for women and men is also indexically linked to class position in a somewhat equivocal way. For while, as I discuss below, movement of a very local kind (particularly walking on the road) can be associated with stigmatized, low-class origins, movement of a more expansive nature can also be understood as a sign of sophistication and education. Movement which involves travel to the larger regional markets and events and especially the capital Georgetown is thus often equated with a kind of worldliness which is opposed to the supposed ignorance of a purely rural lifestyle. Women thus have many reasons for traveling and restrictions on their movement are often understood as placing serious limitations on the quality of their everyday lives.

\section{Space as a social and interactional category in talk}

The cognitive organization of a physical locale into distinct and bounded subspaces always has a certain structure, conceptual organization or topology. Schegloff (1972:103) called this a "commonsense geography". It is this commonsense geography that allows for recognition of place terms in the sense of "the ability to bring knowledge to bear on them, to categorize, see the relevant significance, to see 'in what capacity' the name is used." (Schegloff 1972:111). Geographies of this sort give information on the way in which subspaces are related to one another in terms of inclusion, exclusion and contiguity. As such they play an important role in spatial orientation for discourse production. Schegloff (1972) remarks that, in conversation, the speaker selects from a number of potentially appropriate place formulating expressions, he writes (1972:130):

...on each occasion in conversation on which a formulation of location is used, attention is exhibited to the particulars of the occasion. In selecting a 'right' formulation, attention is exhibited to 'where-we-know-we-are', to 'who-we-knowwe-are,' to 'what-we-know-we-are-doing-at-this-point-in-the-conversation.' A 'right' formulation exhibits, in the very fact of its production, that it is some 'this conversation, at this place, with these members, at this point in its course' which has 
been analyzed to select that term; exhibits, in the very fact of its production, that is some particular 'this situation' which is producing it.

Commonsense geographies thus serve as important resources of background knowledge in talk about space for it is from this stock of knowledge that refererring-terms are drawn. Any place formulating expression potentially describes two distinct spaces which we can distinguish, adapting notation from Jakobson (1957), as the interactive space ( $\mathrm{S}^{\mathrm{i}}$ ) and the narrated space $\left(\mathrm{S}^{\mathrm{n}}\right)$. In conversation, participants talk about or narrate spaces, thus producing descriptions, at the same time as they talk from spaces. This talking from particular spaces similarly, though less obviously, produces a description of sorts. Consider deixis in which the two kinds of spatial description are combined. If I say "he was there" I have designated and narrated something about a space labeled "there". At the same time, because spatial deictics in English generally take the region surrounding the speaker as their indexical ground (see Levinson 1983), I have also indicated a region which is not included in the space denoted by "there" but does include my position at the time of speaking. It is in this sense that we have a description of an interactional space. ${ }^{4}$ Note that whereas distal deictics such as there and that describe distinct and potentially nonoverlapping interactional and narrated spaces, in the case of proximal deictics here and this the two spaces are isomorphic. Finally, comparison should be made to non-deictic expressions such as "he is in the house" which provide information regarding the narrated space only (so that the speaker may or may not be in the house at the time of speaking).

In making spatial description, then, participants draw on the background knowledge of a commonsense geography in giving shape to the interactional and narrated spaces designated in a conversational sequence. Of course the system for formulating place is extremely complicated and I have not attempted to explain the way in which the range of potential denotata for deictic expressions is, in conversation, reduced to manageable number (see Schegloff 1972, Silverstein 1993 for some suggestions). For our purposes it is sufficient to note that place formulating expressions, including deictics, frequently occur in conversations about property, persons and social relations. This cotext provides a frame of relevance for their interpretation.

In the interaction I discuss here, participants draw a local commonsense understanding of geography in formulating place as Schegloff (1972) discussed. In the village the salient oppositions are between house, yard and road. The house is the space most closely associated with the nuclear family and the heterosexual union (Sidnell 1998a, 1998 b). It is contained within the yard which is the property most directly associated with the extended domestic unit, the patrilocal group. In the case I discuss here, the yard is contiguous with the (public) road. These spaces are thus physically organized in the following way: 


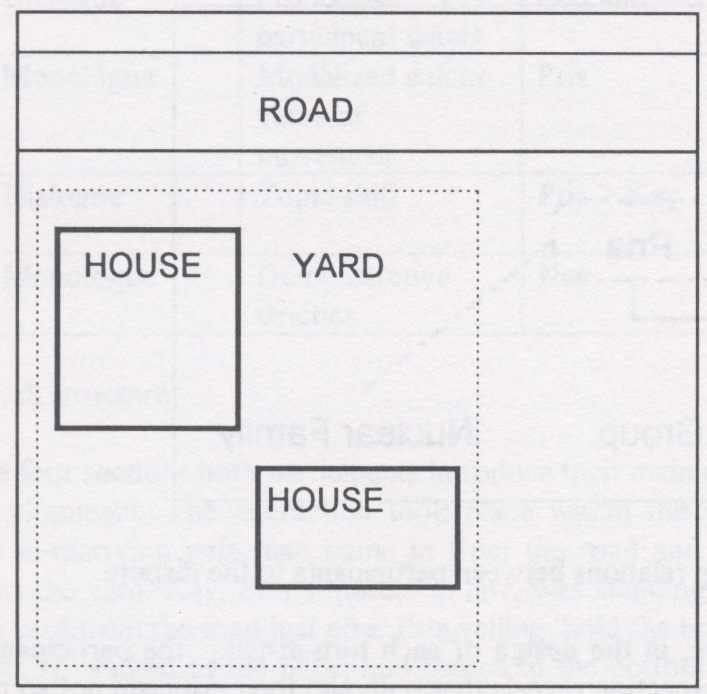

Fig 1. The physical organization of salient local spaces.

This has some bearing on the ways in which space was interactionally negotiated in the talk I discuss here.

Finally, as I mentioned these spaces are associated with particular activities, social relationships and identities. While I reserve detailed discussion of the this point till later, here I will briefly sketch what is involved. The house, the hub of the wife's working world, is generally feminized. Thus a man whom others call a "houseboy" is one who lives like a "woman" refusing the company, and status competition of men in the rumshop (Sidnell 1997). The house is also generally associated with proper behavior befitting good Hindu people joined in sacred union (i.e. marriage). The yard is similarly associated with a certain minimal level of decorum (see Abrahams 1983). Thus the same behavior considered appropriate for the road is shameful when done in the yard. The spaces of the house and yard are propertied and can thus also serve as sources of authority. The owner (or in the case of the yard, the patrilocal group head) can claim authority based on exclusive rights to occupy that space or to manage the behavior of other occupants (see Sidnell 1998b, also Goodwin 1990).

\section{The collaborative activity of disputing}

The dispute I discuss here is a collaborative activity with the two main participants, an inmarrying wife (Pria) and her mother-in-law (Kay), each helping to build their opponent's position. 


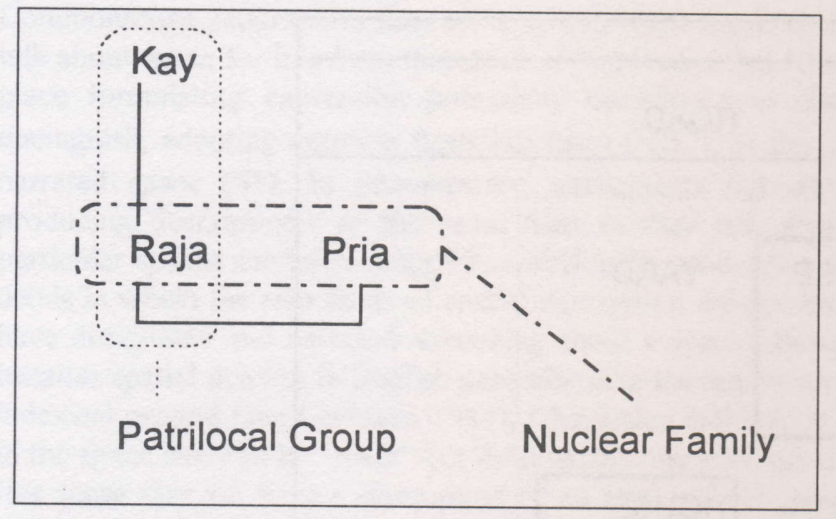

Figure 2. Kinship relations between participants to the dispute

While on the surface, in the design of each turn-at-talk, the participants deftly construct opposition, closer inspection reveals that both aim their criticism not so much at each other as at the socially sanctioned gendering of space and the men who uphold it. At the same time both women construct conversational openings for the other to air her concerns. Despite the tendency to see dispute as human pathology, it is clear from the analysis that opposition, conflict and even the appearance "disorder" in conversational interaction is always a product of the collaboration of the participants involved. Given what I have said about the importance of patrilocal group solidarity and the usual estrangement of affines this collaboration appears particularly remarkable. It forces us to recognize the way in which kinship and gender intersect to allow multiple forms of relationality. While daughter-in-law and mother-in-law are officially opposed both in this interaction and in local understandings of kinship more generally, such 'official' aspects of a relationship mask further complexities of cooperation, collaboration, and I think, even mutual understanding and sympathy. The embedding of a collaborative relationship within an officially oppositional one is also further testament to the partial nature of patriarcal power in this community.

The dispute as a whole can be divided into four sections. Each of these sections is distinguished by an opening and closing, by a distinctive kind of participation, and by the use particular devices for the forgrounding of specific social constructions of space (Table 1). 


\begin{tabular}{|l:l:l|l|l|}
\hline $\begin{array}{l}\text { Sequential } \\
\text { Placement }\end{array}$ & Turn Format & Focal Elements & Speaker & $\begin{array}{l}\text { Interactional } \\
\text { Import }\end{array}$ \\
\hdashline First & Dialogue & $\begin{array}{l}\text { Pronouns- } \\
\text { participant deixis }\end{array}$ & Pria and Kay & $\begin{array}{l}\text { Introduction of } \\
\text { main concerns }\end{array}$ \\
\hline Second & Monologue & $\begin{array}{l}\text { Modalized deictic } \\
\text { verbs of } \\
\text { movement }\end{array}$ & Pria & $\begin{array}{l}\text { Pria voices her } \\
\text { concerns }\end{array}$ \\
\hline Third & Dialogue & Topic shift & Pria $>$ Kay & $\begin{array}{l}\text { Negotiating a } \\
\text { transition }\end{array}$ \\
\hline Fourth & Monologue & $\begin{array}{l}\text { Demonstrative } \\
\text { deictics }\end{array}$ & Kay & $\begin{array}{l}\text { Kay voices her } \\
\text { concerns }\end{array}$ \\
\hline
\end{tabular}

Table 1. An overall structure

In the first of the four sections both participants introduce their main concerns and construct an oppositional alignment. The interaction took place within the yard of one patrilocal group. Pria, the in-marrying wife, had come in from the road and was situated near the gated entrance to the yard. Kay, Pria's mother in law, was standing in front of her house. Raja entered the yard from the road just after Pria yelling "hold the bottom of the gate" to a nearby child (line 3 ), walked to the back, and retired in the bottom house hammock. Kay remained in front of her house. ${ }^{5}$ These spatial relations are sketched in Figure 3.

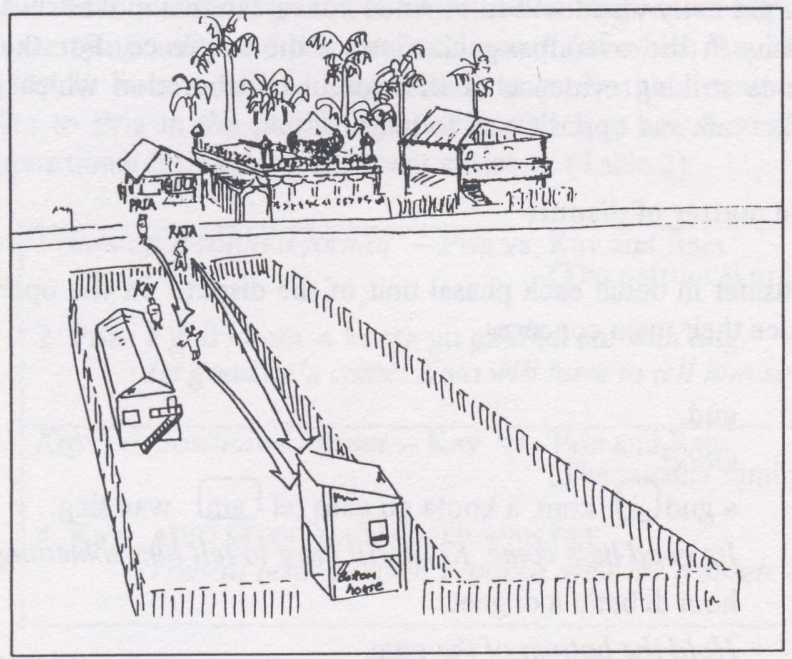

Figure 3. Participants' movements through the spaces of road, yard and house. 
The movements of the participants helps to differentiate major units of talk in the overall organization of the sequence (on the use of the body in differentiating talk units see C. Goodwin 1984, on overall organization see Levinson 1983:308-318). As I have suggested above the interaction can be broken into four units. In the opening sequence (lines 1-9) Pria and Kay indicate their major concerns and their reasons for engaging in the dispute. For Pria this has to do with the over-zealous policing of her movements by Kay, Raja and the rest of the patrilocal unit. Kay's concerns clearly revolve around the relations between her house and Pria's nuclear family. In the course of this opening, Shanka (Kay's daughter and Pria's sister-in-law) moves to a place between Pria and Kay. This section ends with Kay adopting the position which Pria is claiming has driven her to engage in this conflict (specifically she suggests that Pria is "not proper", that is, immoral). Kay thus offers Pria a conversational opening for the airing of her concerns (i.e. the opportunity for disagreement and direct confrontation). This section correlates with Pria moving into the yard space from the road and taking her position facing Kay. The second unit (lines 10-21) contains Pria's major claims regarding the unwarranted actions of the patrilocal group. This is an extended turn at talk which Pria produces facing her principle addressee (Kay). In the third unit (lines 2226), which is a transition point in the interaction, Pria makes a conversational move that is remarkably similar to Kay's earlier one. Thus, when no one responds to Pria's complaints, she changes the topic to that which Kay had introduced in the opening sequence. She thus introduces her opponent's talk just as Kay did for her earlier. This section ends with Pria moving back to her own house. In the final section (lines 27-33), Kay makes her complaints regarding the actions of Pria and Raja. By this time Pria and Raja have retreated and Kay is occupying the space to the side of her own house. The combination of bodily movement through space with precisely timed and formulated conversational moves thus differentiates the most salient units in the overall organization of the sequence. For the analyst such coordinated action is striking evidence of the skillful collaboration which goes into the production of conflict talk and oppositional formats.

\section{Establishing the matter of dispute}

I now move to consider in detail each phasal unit of the dispute. In the opening unit both participants introduce their main concerns.
1. Kay:
gud.
Good.
2. Pria: a gud $\mathrm{i}$ kom. a koota gu gatu tel $\mathrm{am}$ wan ting. Its good he's come. Kota will have to tell him something.
3. Raja: hool di batm a di geet.
Hold the bottom of the gate.
4. Kay: aa AIYU SKONT NA MAIN MI WAN DEE.
All of you (expl.) haven't looked after me a single day. 
AIYU NA GIMINOTIN. (0.5) GUD.

You don't give me anything.

6. Pria:

7. Shanka:

na gu fait huu na beta

I won't fight one $\quad[$ who

man.

who is no better than me.

noo noo fait yu tuu. (1.5)

Don't fight you two.

8. Kay:

yu skont na praa- iivin insaid a hee. (4.0)

9. Kay:

You (expl.) are not proper, even inside of here.

yu skont. (5.0)

You're a bastard.

This is the only section of the dispute which is organized by short turn units in dyadic exchange. This format is however an important feature of the opening as it allows each participant to preface the concerns which become focal in later extended turns-at-talk. Particularly important in the opening is the use of pronominal reference. Specifically, pronouns are used to create the participant framework in which each woman stands opposed to a social group of local importance. In line 2, Pria, the inmarrying wife, uses third person pronouns (i.e. non-participant deictics) to creatively establish a participation framework in which Kay, and not Raja, is the principle addressee. At the same time as this establishes a speaker-hearer dyad between Pria and Kay it also allows Pria to individuate herself in relation to Raja. Further, when combined with the reference to Kota (who is the senior brother in the patrilocal group) it establishes an opposition between an individualized Pria (the in-marrying wife) and the patrilocal group (of which Kay, Raja and Kota are all members). But in lines 4 and 5, Kay refuses to ratify this attempt at individuation and instead refers to Pria in the plural (aiyu). Pria and Kay are thus attempting to establish different oppositional formats in participant structure (Table 2).

\begin{tabular}{l} 
Pria's oppositional format - Pria vs. Kay and Raja \\
(The patrilocal unit) \\
2. Pria: a gud i kom. a koota gu gatu tel am wan ting. \\
Its good he's come. Kota will have to tell him something. \\
$\begin{array}{l}\text { Kay's oppositional format -- Kay vs . Pria and Raja } \\
\text { (The nuclear family) }\end{array}$ \\
$\begin{array}{l}\text { 4. Kay: AIYU SKONT NA MAIN MI WAN DEE. } \\
\text { You-all (expl.) haven't looked after me a single day. }\end{array}$ \\
\hline
\end{tabular}

Table 2. Conflicting oppositional formats 
There is another level at which opposition is collaboratively produced in these first few lines. In line 2 Pria claims that Kota, the big brother in the patrilocal group, will have to "tell" Raja something. In Indo-Guyanese villages one common form of dispute resolution is giving complaint. This involves an offended party asking a superior (a big brother, a father etc.) of the offending party to use their authority to bring that offending party in line. Pria is threatening such an action in line 2. Now, although I have glossed am in tel am somting as "him" (i.e. Raja), the pronoun does not in fact indicate the gender of the referent. The threat is therefore somewhat ambiguous. A few days earlier, Kota had been called in to talk to Kay about her behavior. Although the two had reached an agreement, Kay's behavior in this interaction is quite obviously transgressive. Pria is thus implying that Kota could also be brought into control Kay. Kay is in fact attending to this implication and responds. to it in lines 4 and 5. Kay's response is structured as a parallel construction (Jakobson 1966):

\section{aiyu skont na main mi wan dee}

'All-you haven't looked after me a single day' aiyu na gi mi notin

'All-you don't give me a thing'

Kay here equates general care and concern expressed by the verb mind (/main/) with giving. The verb mind implies not only providing economically but also emotionally. To say that you mind someone in this community means that you are responsible for them. Adults mind children. Kay's parallelism takes giving (money etc.) as an index of minding. The absence of one entails the absence of the other. This constitutes a response to Pria's threat insofar as minding is a relationship of mutual and asymmetrical obligation. Thus, someone who minds you is also someone that you owe something to and whose authority you are obliged to acknowledge. If a woman wishes to repudiate a man's control over her she will say $i$ na main mii 'He doesn't look after me.' If a man says this about another man the imputed/disputed relation implied is one between father and son, big-brother and littlebrother. Thus Kay implies that Pria's threat is empty. Since they do not mind her they have no right to tell her what she can and cannot do, where she can go, or how she must behave.

In this section of the dispute, distinguished by dyadic participation and by growing pauses after each turn, pronouns also become the salient indices of spatial organization. The pronouns foreground particular perspectives on spatial organization by virtue of a strong connection between particular spaces and the people who inhabit them (Figure 4).

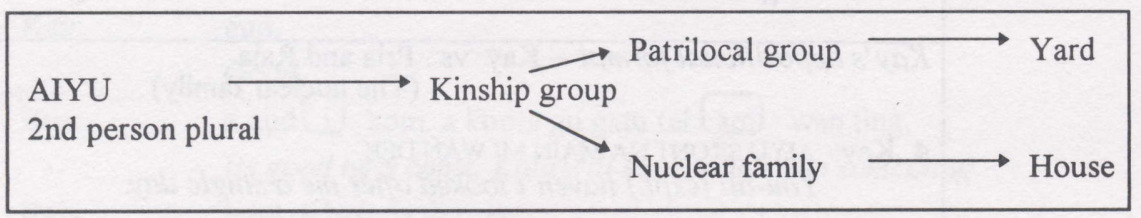

Figure 4. Series of Associations between contextualized pronoun, kinship group and locatable spaces. 
This initial spatial opposition between house and yard reappears in a number of guises throughout the interaction particularly the last section in which Kay speaks (lines 28-33). In reference to the first section of the dispute currently under discussion, note that Kay's remarks in line 4 draw on her construction of Pria and Raja as constituting a nuclear family which is a single domestic unit, has its own internal structure and has relations, as a single unit, with others. Her use of here in line 8 however refers to the yard as this is the only locally recognized space which she could be said to be "inside of" at the time of speaking. In her talk Kay thus links Pria's immoral behavior to expectations for proper conduct in specific places. By ending her assessment of Pria's behavior with insaid hee 'inside here' she makes the connection between place and comportment explicit.

I have said that the women collaborate to jointly produce the oppositional framework of the dispute and that each allows the other a chance to air her concerns. In this regard, notice the way in which, in the last few lines of this section, Kay returns to the subject of Pria's immorality. This section ends with Kay adopting the position which Pria is claiming has driven her to engage in this conflict (lines 8 and 9), specifically, she suggests that Pria is "not proper." While constructed as a reply to Pria's immediately preceding comments in line 6, Kay in fact quite subtly turns the dispute to the question of Pria's movement. For in saying that Pria's behavior is not proper "even inside" the yard, Kay draws attention, through contrast, to Pria's activities and movements outside this space. Kay thus offers Pria a conversational opening for the airing of her concerns, that is, an opportunity for disagreement and direct confrontation.

Further evidence of collaboration is to be found in the first few lines of this opening section. We can thus note that, in line 6 , Pria explicitly ratifies an oppositional alignment between herself and Kay. This is complex move by Pria for while she acknowledges the emergence of opposition (i.e. a "fight") she claims that she will not engage in such an activity. The reason given for this purported non-engagement is (moral) equivalence between herself and Kay. Pria claims specifically that she will not fight with someone who is no better than herself. In fact, this statement, far from removing her from the opposition, furthers her earlier veiled threat to inform Kota of Kay's behavior. Pria's suggestion of an equivalence between herself and Kay, while disguised as a withdrawal from conflict, points to the possibilities of a counter attack, one in which Kay's own transgressions of patrilocal authority are held up to scrutiny.

Even in these few lines, then, the interlocutors have introduced discourse entities (participants, social groups) which have readily recognizable relations to spatial organization. At the same time, the participants combine place-formulating expressions with body movement to further contextualize their claims and counter-claims. Note the nonobvious way in which Pria situates herself within the yard space but at a remove from Raja's small house at the back through the use of deictic kom "come." Her spatial placement, as she constructs it, thus supports both her claim to individuation (because she separates herself from the family's house) and the defense of her own actions (she is not now on the road - she has returned). When she says a gud $i$ kom... she uses her own position in interactive space as indexical origo (see Fillmore 1973). Her presupposed position in relation to socially meaningful spatial arrangements of the house and the yard 
thus becomes part of the background knowledge on which she draws later in the interaction. Kay is also construing the spaces of the house and yard in a particular way. As I have noted, she stresses the independence of the two households. This analytical separation of the house from its surroundings becomes the focus of her attack later in the exchange.

\section{Modality, morality and irrealis worlds}

In the second section of the dispute, Pria launches into a monologue. A question we might ask is how this shift from dialogue to monologue is achieved. A monologue, by definition, is constituted by a suspension of the turn-taking system for ordinary conversation (Sacks, Schegloff and Jefferson 1974) and as such is jointly achieved by the co-participants despite the fact that only one person speaks during its course. In view of this, note that Pria's first turn in this section is a complaint (shi kyan gu out an mi kyaan gu noowee "She is can go out, and I can't go anywhere"). An expectable response in Guyanese conversation as in other communities might be either a remedy or an expression of agreement (see Pomerantz 1984). However, Kay, Pria's immediate interlocutor to this point in the interaction, is not in a position to give a remedy (she does not have ultimate authority in the matter of Pria's movement) and is unlikely to respond by agreement (an expression of empathy) given the fact that her own actions are now being used as a point of contrast in Pria's talk. Furthermore, Pria refers to Kay in this opening complaint using the third person pronoun (non-participant deictic). She has thus designed her opening turn in such a way that potentially excludes response and further participation by Kay. The fact that the complaint is left without a response adds to its identification as a publicly directed plea. Note that this emerging monologue is delivered in a high-pitched and markedly louder voice than Pria's previous talk. She uses a number of affect marking features to index a heightened emotional state locally referred to as "passion" including an increased amplitude, higher pitch, curse words (eg. skont, ras) and rhythmic, parallel structures. In terms of the participant structure, Pria is again attempting to distance herself from her husband Raja in her use of a $m i$ " $\Gamma$ " vs. $i i$ "he" contrast (lines 10 and 11). Looking ahead, we can see that Kay will again refuse to ratify this individuation and instead addresses Pria in the plural (aiyu and dem) repeatedly (lines 4 and 5, see also "dem" in lines 27 and 28).

10. Pria: shi kyan gu out an mi kyaan gu noowee. (0.5)

11. ii mos tel mii wat a klak mi mos

He has to tell me what time I most go

(huu) wat a klak mi mos kom bak (0.7)

(who) what time I most come back.

13.

mi kyaan gu a rood noowe.

14.

I can't go on the road anywhere.

yu mos kom an luk fo mii an saarch fo mii 


\section{You must come and look for me and search for me}

15.

16.

17.

18.

19.

20.

21.

mi no noo wa skont yu a luk fo mii

\section{I don't know why the hell you look for me}

an saarch fo mii mi na noo. (1.0)

and search for me, I don't know.

MII DON TEL YU IF MI WAN TEEK MAN ras

I've already told you - if I want to have another man (ras)

yu kyaan stap mii. (7.0)

you can't stop me.

mii a big homan fo miself

\section{I am my own adult woman}

an mii mos noo rang an mii mos noo rait.

and I have to know what is wrong and know what is right

so mi na frigin onastan wa mek ii ga saarch fo mii. (5.0)

so I don't (frigin) understand why he must search for me.

Pria's attack here is not only directed at Raja but at the patrilocal unit as well. This is particularly apparent in Pria's alignment of the participants. Note then that she initially refers to both Kay and Raja using 3rd person, nonparticipant deictics (Kay in line 10 and Raja in line 11). So to whom is this segment addressed? Shanka is close by but the volume with which Pria delivers this stretch of talk indicates that she wants her words to reach other ears. The audience, it appears, is essentially anybody who will listen. By this time a number of people were gathered outside the fence which marks the extent of the yard. Her talk in this way breaches an important boundary which divides the space of the patrilocal group from that of the village as a whole (i.e. the yard fencing). At the end of line 13, having made her complaint public, Pria takes Raja as her principle addressed recipient. The content of her speech here focuses directly on the social meanings of spaces and the movement of individuals within them. She uses modal kyan "can" and kyaan "can't" to characterize a realm in which social actors' use of, and movement through, space is limited by conditions of possibility and obligation. ${ }^{6}$ Kay is free to walk about but Pria's movement is restricted by Raja's supervision. This irrealis world that Pria constructs recreates the spatial arrangements of the house and the road. Thus Pria uses the referring expression $a$ rood ("on the road") along with the deictic verbs gu "go" and kom "come" in orienting participants to this hypothetical space modeled after the one they are currently inhabiting. Note that the indexical ground on which these verbs rely for their interpretation is not, in this case, the position of the speaker at the time of speaking. Modals effect a transposition of this ground and substitute for it a hypothetical one thus detaching the description of a narrated space from the interactive space within which it is formulated. Although when Pria uses gu "go" (lines 10 and 11) the irrealis and realis grounds match, when she uses kom "come" the ground is transposed to somewhere outside the spaces of the house and yard. 
So Pria is not only creating a hypothetical world in which she is situated outside these boundaries but is also taking as the ground for her utterance the place at which Raja will (or does) find her. There is an ambiguity again here. Pria is claiming that Raja's behavior is unwarranted and shameful because she only goes to visit friends and family. At the same time she implies that this place where Raja will find her could be the site of a transgression of the heterosexual union. The latter interpretation seems consistent with the next line (17) in which Pria increases her volume to tell Raja (and the overhearing participants) that she can take another man if she wants to and he can't stop her. But this threat is mitigated when she claims status as a "big-woman". Most importantly, Pria is arguing that she is a mature adult and should be granted respect and rights to autonomy that go along with such status. She concludes with a claim about the fundamental moral autonomy of the mature and capable person. ${ }^{7}$

Pria's remarks here are met with silence from the other co-participants despite the long pauses at the termination of talk in lines $16,18,21$. These are obviously transition relevant points as Pria, in each case, comes to possible syntactic and intonational completion. But Pria's interlocutors refuse to engage her and thus do not ratify what she is saying. As I have noted this absence of a response is part of the way in which this section is achieved as a monologue. Pria then makes a rather surprising move in line 22 . In this transitional third section Pria uses the plural deictic in self-reference thus aligning herself with Raja and asserting the relevance of the nuclear unit. By this she now ratifies the participation framework that Kay had tried to establish in the first few lines. Furthermore, Pria now brings the talk back to the topic that Kay had originally introduced - that is, the economic relations between the two houses by commenting on a loan that has not been repaid. In a striking instance of collaboration within the midst of conflict this move brings Kay back into the exchange. Kay reasserts the oppositional structure in line 24 through an obviously aggressive interruption, upgrading her contribution so as to drown out Pria. Sequences like this in which one participant constructs a conversational opening for another provide fairly incontrovertible evidence that, despite the appearance of disorder in conflict talk, participants collaboratively produce opposition through close attention to the content, form and sequencing of prior talk and their interlocutors positioning (a point made persuasively by Goodwin 1983, Goodwin and Goodwin 1990).

22. Pria:

abi aks wa kom pan tuu twenti eet. yuu see wan faiv-

We asked what was left from two-twenty eight you said five

24. Kay:

LEMI $\quad$ TEL YU SOMTING. yu mós tink a

Let me tell you something. You most think this is

25 .

Raja daadii prapatii. A MII PRAPATII DIS.

Raja's father's property - this is my property 
26.

an mi hozban prapatii.(1.7) gud.

and my husband's property good!

A few final observations about this finely coordinated transition are in order. With regard to the stretch of overlapping talk in lines 23 and 24, note the way in which Pria abandons her turn just after that point where Kay begins in overlap. This precision restart and reshaping of the turn in fact displays to the co-participants her commitment to continue talking without regard to matters of possible turn-completion. Note then that she is not at this point working toward completion but is rather starting out afresh with a new turn constructional unit. The overlapping speech here, while appearing "disorderly" on first inspection (and overlap is typically taken by observers, both academic and immediate, as the first stage in the demise of orderliness in conversation cf. Schegloff 1988/89) exhibits a kind of extreme orderliness in its manner of production. As Schegloff (1988/89:229) notes:

[...] the vernacular view of overlapping talk is that it may impair hearing or understanding $[\ldots](0) n$ the other hand, it is regularly the case that the simultaneously speaking participants demonstrably do attend to what the other is saying - "demonstrably" because they exhibit the product of that hearing in their own subsequent conduct.

In another context, Schegloff (nd:25) suggests that, "there is some evidence that parties to talk-in-interaction can orient to syllable-like beats in monitoring and producing the talk." In this respect not the apparent phonological matching achieved in lines 23 and 24 .

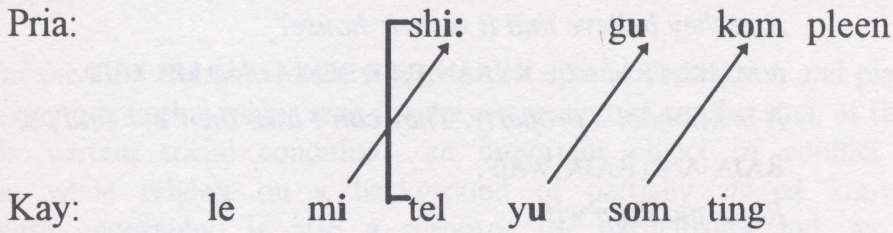

We find Pria matching in her own speech the most salient phonological material (the vowel) of Kay's talk at the next possible opportunity after its delivery. In order to achieve this Pria in fact abandons her turn in progress ( $y$ u see wan fiav "you said five") and begins a new turn (shi gu compleen "she will complain").

Note also the way in which Kay projects further talk to come with the preface le $m i$ tel yu somting "let me tell you something." This projection of an extended spate of talk, projectably complete at the point when Kay will have told Pria something (that is something consequential), parallels Pria's earlier projection of an extended spate of talk through her use of complaints which call for, but cannot, in this context given the structure of participation, receive a response. This transition is thus a joint production constructed over 
a series of phases: initiated by Pria's reassertion of an earlier topic as well as by her shifting of the participation framework and then taken up in Kay's preface and subsequent talk.

\section{Dispute closure without resolution}

In the final section of the dispute, Kay concludes with a monologue very much like the one Pria delivered in terms of its sequencing and pacing. Kay uses what Schegloff (1972) called an $R_{m}$ expression for "relation to members". Such expressions point to a "belongingness" relationship of person to place. The specific claim Kay is making goes deeper than this however. She not only claims that she belongs to this space but also contests Raja's (and, by extension, Pria's) rights to any part of it. She uses the proximal demonstrative dis "this" as post-position (a mii prapatii dis "This is my property") to reference a space which is within her immediate perceptual field. The referent of dis is clearly the yard as a whole (which she presents ostensively to the audience) and the form relies, for its interpretation, on the notion of a unit of land tied to the patrilocal group as indicated in the surrounding co-text (an mii hozban prapatii "and my husband's property" line 26 ). So Kay here claims to own the entire yard and at the same time characterizes this space as undivided and homogenous (so that $d a$ would in this contrastive set refer to something located outside the perimeter of the yard). In fact Kay's claims to property rights do not match local expectations or rules of inheritance. She continues:

27. Kay:

NONBADII KYAN NOT TEEK DEM AI PAS MII TODEE.

Nobody can take their eye and pass me today.

28.

AN DEM BILIIV A DEM HOUS?

And they believe that it is their house?

29.

A MAIKL PRAPATII. KYAAN TEEK DEM AI PAS MII. GUD.

It is Michael's property. They can't take their eye and pass me. Good. RAJA AND RAJA WAIF.

Raja and Raja wife.

<pause 26.0>

31 .

WAN KRAS DE INSAI DIS HOUS NO?

There is a cross inside this house, no?

A KRAS. A KRAS. LAIK AIYU SKONT KYAAN DON TAAK. (NOTIN KYAN) A cross. A cross. It looks like all-of-you bastards can't stop talking. YUU RICH AZ DA KANKRIIT BATMHOUS AN SO. A KRAS.

You're as rich as that concrete bottomhouse and so on. A cross.

What is particularly interesting about this final section is the way Kay uses dis "this" to refer to Raja's house (line 31 ) thus bringing it into the same proximal frame of the yard. 
Remember that this is the space over which she has claimed ownership through the authority of her dead husband (line 25-26). Immediately after this she refers to the concrete bottomhouse using the distal demonstrative $d a$ "that" in line 33. This situates Raja, who is seated in the bottomhouse, outside the space associated with the patrilocal unit. Moreover, the opposition of proximal to distal spatial frame establishes a boundary between what Kay claims as her property (including the yard and Raja's house) and what she construct's as Raja's property (the concrete bottom house). ${ }^{8}$ Although dis and da do prototypically make reference to physically proximal versus physically distal locations, this usual interpretation can be suspended in certain contexts. The house (referred to as dis) and the bottomhouse (referred to as $d a$ ) are at exactly equal distances from Kay at the time of speaking. Kay uses the default values of these demonstratives to characterize space in terms of social, rather than physical, relations. As Levinson (1994:857) notes, "( $\mathrm{t}$ )here are many sociological aspects to [...] deictic dimensions, e.g., whether to describe some space as 'here' or 'there' may depend on whether one thinks of it as near 'us' or near 'them,' this being sociologically defined."

In this, the final section of the dispute, we find no indication of a resolution. Notably, while both Kay and Pria have now presented their own argument, neither has explicitly addressed the others' concerns. Thus although Kay's remarks here achieve a closure to the sequence they do so without an obvious resolution. Both participants have addressed different aspects of the relationship between space and gender in this community. The collaborative nature of this interaction can thus be seen as providing a context within which it is possible to air concerns staged in terms of opposition while not working towards a resolution.

\section{Conclusions}

Evidence of the kind examined here suggests that spatial description and place formulation in verbal dispute is both a major area for the expression of conflict and, at the same time at least under certain social conditions, an important object of conflict itself. Spatial orientation, while relying on a background of partially shared knowledge (i.e. a commonsense geography) is also a resource for participants and, as such, can be strategically manipulated to achieve interactional goals such as the production of oppositional formats and participant structures. In the specific case I have discussed here, women collaboratively produced an oppositional framework and dispute frame in which it becomes possible to criticize the existing social order, specifically the local gendering of space. The social and interactional construction of space is shown to be at once tied to the exercise of social power and its contestation.

I have argued that participants to this dispute deployed practices of talk-ininteraction so as to jointly produce a dispute in which criticisms of the social order could be voiced. I have attended both to the collaborative aspects of this dispute and the more obviously political aspects surrounding issues of space, morality and gender. Ultimately the purpose is to show the way in which the two aspects of the dispute are mutually embedded. It is only through the collaborative actions of the participants that this kind of critical 
political voice in the community can emerge. Importantly, it seems that a condition for the emergence of this critical voice is its disguise as opposition between disputing women. Examining the details of the dispute however reveals multiple levels of collaboration.

\section{Acknowledgments}

Research in Guyana between 1994 and 1996 was funded by the Social Sciences and Humanities Research Council of Canada and the Wenner Gren Foundation for Anthropological Research. This paper has greatly benefited from the detailed comments of a number of readers. I would particularly like to thank, Candy Goodwin, Lanita Jacobs Huey and Bonnie McElhinny. A previous version was presented at the 96th annual meetings of the American Anthropological Association Meetings. For their comments and suggestions at that time I thank Bill Hanks and John Haviland. I am also indebted to Manny Schegloff for his comments on a number of specific points in the analysis. None of these people should be held responsible for any remaining inadequacies as I have not heeded their advice in every case. I owe a great debt to Pria, Kay, Raja and my other friends and hosts in Guyana who have contributed to this work in multiple of ways.

\section{Notes}

1 The following is an analysis of a single episode of interaction. As I have suggested the case I discuss here is in some ways an example of a larger class of like-events. However noting that this example can be seen as an instance of a more general class should not distract from the major claim in this paper that the dispute's overall structure, the various alignments between participants, and the phases of transition were in the first instance achieved through the collaborative activity of the co-participants. I have thus attempted to ground all analytic observations in what is demonstrably relevant to the participants who produced this dispute rather than in some sense of what "generally" happens in this community. On the utility of studying single episodes see Schegloff 1987.

2 For the sake of simplicity, readability and consistency I have used the phonemic transcription system originally devised by Cassidy (1971 [1961]) and elaborated in Rickford (1987). Most of the characters are equivalent to IPA symbols, exceptions which occur in the transcripts here are listed below (adapted from Rickford 1987:7-9):

sh [] voiceless alveopalatal fricative

ch [t] voiceless alveopalatal affricate

$y$ [j] palatal approximant/semi-vowel

ii [i] high, tense, front unrounded

$i$ [I] lower-high, lax, front unrounded

ee [e] mid, tense, front unrounded 
e $[\varepsilon]$ lower-mid, lax, front unrounded

a [a] low/open, short, central unrounded

aa [a:] low/open, long, central unrounded

ai [ar] falling diphthong

$o \quad[\ominus]$ short, central unrounded, unstressed, or $[\Lambda]$ short, back unrounded, frequently (but not always) stressed

ou $[\wedge \mho]$ falling diphthong

oo [o] long, mid, back rounded

$u \quad[\circlearrowright]$ lax, lower-high, back rounded

uu [u] tense, high, back rounded

Other transcription conventions are adapted from Sacks, Schegloff and Jefferson 1974: indicates falling, final intonation.

? indicates rising intonation.

- $\quad$ indicates a self-interruption.

NO small capitals indicate an increase in amplitude relative to surrounding talk.

[ brackets mark the onset of overlap.

(0.2) marks a pause or gap in tenths of seconds.

${ }^{3}$ Given the gender of the participants and the potential for reproducing existing stereotypes of men and women it is necessary to say a few words about the social foundations of interpersonal conflict in this community before moving to an analysis of the transcript. In Guyana, as in a number of other places (see for example Kulick 1994), women have a widely accepted reputation for being argumentative, divisive and prone to verbal dispute. Such a stereotype exerts considerable influence both on native accounts of verbal interaction (Sidnell 1997) and scholarly writings (for an example see Edwards 1978). Despite the tendency to psychologize and gender argument in this way (treating it as the inevitable expression of an essential femininity), it is in fact apparent that certain social forces tend to give shape both to the production of conflict and local interpretations of its verbal manifestation. The first thing to note is the way in which women, particularly married and junior women (i.e. daughters), often find themselves living under the authority of a senior man. Residence is primarily patrilocal so that married women tend to live with their husband's families. Patrilocal units, consisting of several nuclear families occupying a plot of patrilineally inherited land, have a very public face. Others tend to judge an individual's actions in terms of the overall character of the group and this leads group members to vigorously defend their reputation or name against scandal. The result is a situation in which women, more than men, find it necessary to cultivate moral persons that are "respectable" and "proper". In the face of a very active gossip-system women are frequently called upon to publicly defend themselves and their actions. This then leads women to engage in certain kinds of dispute which men generally avoid.

The other major implication of the patrilocal social system which is relevant to what follows has to do with the organization of space and the regulation of movement. Within 
the village gossip-system, evidence of immoral or disrespectable behavior is often creatively generated. Thus, seeing someone on the road and headed in a certain direction is often taken as an indication that that person is making an illicit visit to a lover. Circumstantial evidence of this kind can be very damaging to the personal reputation of both a woman and her husband. Husbands who are considered to have unfaithful wives are the objects of much derision. Added to this is the widely held belief among men that women cannot be trusted and must therefore be controlled by senior men (i.e. a father or a husband). In an attempt to preserve and protect their own reputation and "good name", then, men make strenuous efforts to keep women at home under the watchful eye of their own patrilocal group. Married women must always have a reason and an intended destination when going out. Policing the movement of bodies through space thus becomes a primary arena for the exercise of male authority and power. Women, however, do not always submit to the regulations of senior men. They frequently devise reasons for leaving the house and engage in visiting on a regular basis despite their husband's, sometimes firmly physical, reprisals. Women are often forced to defend their rights to movement and their general personal autonomy against the impositions of their affinal patrilocal group. This tension between wife and patrilocal group, expressed in terms of rights to movement, thus also leads to a greater involvement by women in certain kinds of verbal dispute.

${ }^{4} \mathrm{Hanks}$ (1992) and Silverstein (1993) call this the metapragmatic function of deixis because it involves descriptions of the relationship of a message or signal to its context of occurrence. The relation between $\mathrm{S}^{\mathrm{n}}$ and $\mathrm{S}^{\mathrm{i}}$ has been discussed in terms figure and ground relations (Hanks 1992). I have chosen the current terminology to emphasize the similarities between deictic and nondeictic formulations.

${ }^{5}$ Pria and Raja had established a small roadside stand about four months before the events discussed here took place. At this stand they sold salseeoo with saurii (a local snack made with flour and water), biscuits, and cigarettes to people passing by as well as to young boys and girls, adolescents and adults who were, for one reason or another, on the road. Pria ran the Queen Bee as her own project - it had been her idea, she made the salseeo, she kept the little book of debts.

Most of the regular patrons were men between 15 and 25 years old who lived in the immediate vicinity. They would come to sit on the bench, gyaf, smoke cigarettes and occasionally to play cards. Located near a number of locally important houses, the stand became a popular spot to meet friends and lime "hang out". Often one found ten to fifteen people lined along the road. Many of the men and boys were Raja's nephews who lived in the same and neighboring yards. Another group of about 4-5 young men (ranging from 20 to 25 years in age) also met regularly at the stand usually around six or seven o'clock. They were better off economically than most - one owned a car, another had a stake in a large coconut estate, another was a teacher. One of them, George, whose father was the owner of various properties including a hotel, became quite good friends with Pria. They would sit next to each other and gyaf and joke. Rumor that the two were carrying on an illicit affair 
did not take long to spread. Soon everybody seemed suspicious. Raja got word of this and became much more protective and involved in the stand's operations. He would come out early, tell Pria to go inside the house and sell the goods himself. In various way he let George know that he was no longer welcome. The gossip became more intense however and when Raja went to his sister Gigi's for an overnight stay he returned to find Pria involved in a new story. Apparently, Pria had signaled from her verandah to George who was riding his bike along the road at dusk. Raja's nephews said they had watched her as she indicated that Raja was out of the house and that he should enter through the backdam. Raja, who took his suspicions of his wife's infidelity to be confirmed, intensified his watch. He demanded that she stay home. He demanded that she ask for permission to leave the house when she had somewhere to go. When she stayed too long he would come and collect her. Other members of the extended patrilocal unit also intensified the watch. This included Kay, Raja's mother, who lived in the main house in the same yard. A widow, Kay enjoyed certain kinds of freedoms not usually associated with younger women. As a woman of 65 years she was removed from the heterosexual market place and was therefore allowed to walk out when she pleased. In fact she was known as a walker. This caused some embarrassment to the family too. According to them she was often drunk and bathed infrequently.

${ }^{6}$ I think the sense - epistemic or deontic - we give to these auxiliaries in this context depends on the interpretation vis. a vis. a surrounding co-text. Pria could be indexing a world of impossibility (an epistemic interpretation) when she says mi kyaan gu nowee if we take this as an outcome of the social world (I can't go anywhere - I have too much work to do). The deontic meaning is perhaps more direct (I can't go anywhere because other people stop me).

${ }^{7}$ It is interesting to note the alternation modal $k y a(a) n$ 'can('t)' and modal mos 'must'. Whereas kyan is somewhat ambiguous between epistemic and deontic meanings, mos is (in this case) unambiguously deontic predicating as it does a domain of obligation. In line 11 (ii mos...) the obligation is predicated of Raja - (i.e. Raja is obliged by his own sense of male authority to come look for her). In line 20 , however, the source of obligation shifts from Raja's moral authority to a more general social ethic. In line 20 Pria is evoking a world of rights and obligations deriving from social and community norms (i.e. a big-woman is responsible for her own moral actions).

${ }^{8}$ The insult is meant to go further than simply saying Raja is not the owner of his own house and yard. Kay is charging that Raja must live by the charity of others. About a week and half earlier I had given Raja the money to lay concrete over the daub floor of the bottomhouse. The two of us spent a couple of days laying it out and filling it in with sand, rock and concrete. Everybody in the yard knew what we were doing and who had financed it. 


\section{References Cited}

Abrahams, Roger (1983) Symbolic landscapes and expressive events. In The Man of Words in the West Indies: Performance and the Emergence of Creole Culture. Baltimore: John Hopkins University Press.

Cassidy, Fredric .G. (1971[1961]) Jamaica Talk: Three Hundred Years of the English Language in Jamaica. 2nd ed. London: Macmillian.

Duranti, Alessandro (1994) From Grammar to Politics: Linguistic Anthropology in a Western Samoan Village. Berkeley: University of California Press.

Edwards, Walter (1978) Tantalisin and Busin in Guyana. Anthropological Linguistics, Vol. 20, No. 5 .

Fillmore, Charles (1973) May we come in? Semiotica, 9: 97-116

Foucault, Michel (1979) Discipline and Punish: The Birth of the Prison. New York: Vintage Books.

Goodwin, Charles (1984) Notes on story structure and the structure of participation. In J.Maxwell Atkinson and John Heritage eds. Structures of Social Action: Studies in Conversation Analysis. Cambridge: Cambridge University Press.

Goodwin, Charles and Marjorie H. Goodwin (1990) Interstitial Argument. In A.D. Grimshaw ed. Conflict Talk: Sociolinguistic Investigations of arguments in conversation. Cambridge: Cambridge University Press.

Goodwin, Marjorie H. (1983) Aggravated correction and disagreement in children's conversations. Journal of Pragmatics, 7. 657-677.

Goodwin, Marjorie H. (1990) He-Said-She-Said: Talk as Social Organization among Black Children. Bloomington: Indiana University Press.

Hanks, William (1990) Referential Practice: language and lived space among the Maya. Chicago: University of Chicago Press.

Hanks, William (1992) The indexical ground of deictic reference. In A. Duranti and C. Goodwin eds. Rethinking Context: Language as an interactive phenomenon. Cambridge: Cambridge University Press. 
Hanks, William (1996a) Language and Communicative Practices. Boulder, CO: Westview Press.

Hanks, William (1996b) Language form and communicative practices. In John Gumperz and Stephen Levinson eds. Rethinking Linguistic Relativity. Cambridge: Cambridge University Press.

Jakobson, Roman (1957) Shifters, verbal categories, and the Russian verb. In Selected Works II: Word and Language. The Hague: Mouton.

Jakobson, Roman (1966) Grammatical parallelism and its Russian facet. Language 42: 399429.

Keating, Elizabeth (1994) Language, gender, rank and social space: Honorifics in Pohnpei, Micronesia. In Cultural Performances: Proceeding of the third Berkeley Women and Language Conference, Berkeley: Berkeley Women and Language Press.

Kulick, Don (1993) Speaking as a Woman: Structure and gender in domestic arguments in a New Guinea Village. Cultural Anthropology 8(4):510-541.

Levinson, Stephen (1983) Pragmatics. Cambridge: Cambridge University Press.

Levinson, Stephen (1994) Deixis. In RE. Asher ed. Encyclopedia of Language and Linguistics, 2:853-57. Oxford: Pergamon.

Moore, Henrietta (1986) Space, Text and Gender: An Anthropological Study of the Marakwet of Kenya. Cambridge: Cambridge University Press.

Ochs, Elinor (1988) Culture and Language Development: Language Acquisition and Language Socialization in a Samoan Village. Cambridge: Cambridge University Press.

Pomerantz, Anita (1984) Agreeing and disagreeing with assessments: some features of preferred/dispreffered turn shapes. In J.Maxwell Atkinson and John Heritage eds. Structures of Social Action: Studies in Conversation Analysis. Cambridge: Cambridge University Press.

Rickford, John (1987) Dimensions of a Creole Continuum. Stanford: Stanford University Press.

Sacks, Harvey, Schegloff, Emmanuel and Gail Jefferson (1974) A simplest systematics for the organization of turn-taking for conversation. Language, 50, 696-735. 
Schegloff, Emmanuel (1972) Notes on a conversational practice: Formulating place. In Peter P. Giglioli ed. Language and Social Context, Harmondsworth: Penguin.

Schegloff, Emmanuel (1987) Analyzing single episodes of interaction: An exercise in conversation analysis. Social Psychological Quarterly, Vol. 50, No. 2: 101-114.

Schegloff, Emmanuel (1988/89) From interview to confrontation: Observations of the Bush/Rather encounter. Research on Language and Social Interaction, Vol. 22: 215-240.

Schegloff, Emmanuel (nd) Interruption, Overlap and Turn-Taking: Accounts of Conduct in Interaction. Unpublished Manuscript.

Sidnell, Jack (1997) Gyaf: How men negotiate status and authority in an Indo-Guyanese village. Paper presented at CLIC (Center for Language, Interaction and Culture), UCLA.

Sidnell, Jack (1998) Gender, Space and Linguistic Practice in an Indo-Guyanese Village. $\mathrm{PhD}$ Dissertation, University of Toronto.

Sidnell, Jack (1998b) Elicitations as a resource for organizing social and spatial location in an Indo-Guyanese Village. Journal of Linguistic Anthropology. 7(2): 1-23.

Silverstein, Michael (1993) Metapragmatic discourse and metapragmatic function. In John Lucy ed. Reflexive Language: Reported Speech and Metaprgamatics, Cambridge: Cambridge University Press.

Winford, Donald (1993) Predication in Caribbean English Creoles. Amsterdam: John Benjamins. 